引用格式: 吴霞, 王培娟, 霍治国, 等. 1961-2015 年中国潜在蒸散时空变化特征与成因 [J]. 资源科学, 2017,39(5):964-977. [Wu X, Wang P J, Huo Z G, et al. Spatio-temporal distribution characteristics of potential evapotranspiration and impact factors in China from 1961 to 2015[J]. Resources Science, 2017,39(5):964-977.] DOI: 10.18402/resci.2017.05.16

\title{
1961-2015 年中国潜在蒸散时空变化特征与成因
}

\author{
吴 霞, 王培娟, 霍治国, 白月明 \\ (中国气象科学研究院, 北京 100081)
}

\begin{abstract}
摘 要: 基于中国 552 个气象站点 1961-2015 年逐日气象数据, 利用 Penman-Monteith 公式得到各站点逐日 $E T_{0}$, 以全国和各千湿气候区为研究单元, 从年、季节和年代际尺度分析 $E T_{0}$ 的时空分布特征及其变化成因。结 果表明: 全国各站点年平均 $E T_{0}$ 为 $621 \sim 1733 \mathrm{~mm}$, 在年、年代际尺度表现为千旱区 $E T_{0}$ 最高、半千旱区和湿润区次 之、半湿润区最低; 季节尺度上, $E T_{0}$ 的空间分布存在明显差异,且夏季 $E T_{0}$ 最高、春秋季次之、冬季最低。全国年 平均 $E T_{0}$ 以 $0.52 \mathrm{~mm} / \mathrm{a}$ 的速率递减, 该下降趋势在 1972 年存在突变现象; 千旱区和湿润区大部分站点 $E T_{0}$ 呈减小 趋势, 且千旱区减小速率较快; 而在半千旱区和半湿润区, $E T_{0}$ 呈增加和减小趋势的站点数大致相当。研究表 明,1961-2015 年中国 $E T_{0}$ 呈减少趋势主要是由风速减小、日照时数降低和水汽压微弱增加共同导致的, 而 $20 世$ 纪 90 年代以后 $E T_{0}$ 的增加趋势主要受水汽压、日照时数和最低气温的共同影响。
\end{abstract}

关键词: 潜在蒸散; 千湿气候区; 时空分布特征; 变化成因; 中国

DOI: $10.18402 /$ resci.2017.05.16

\section{1 引言}

潜在蒸散 (potential evapotranspiration, $E T_{0}$ ) 是 指假设平坦地面被特定矮杆绿色作物 (高 $0.12 \mathrm{~m}$, 叶 面阻力 $70 \mathrm{~s} / \mathrm{m}$, 地面反照率为 0.23 ) 全部遮蔽, 同时 土壤保持充分湿润情况下的蒸散量,也称可能蒸散 量或参考蒸散量 ${ }^{[1]}$, 它是表征大气蒸发能力的一个 量度, 是实际蒸散的理论上限值, 也是计算实际蒸 散的基础。同时,潜在蒸散也是评价气候干湿程 度、水资源利用状况、作物耗水和作物生产潜力的 重要指标, 是制定作物灌溉制度和区域灌溉需水量 计划的基本依据,对于预测作物水分需求、分析气 候变化对作物的影响和农业干旱分布等方面均具 有重要意义。

近年来, 许多专家学者在 $E T_{0}$ 方面开展了大量 工作, 研究表明中国 $E T_{0}$ 的空间分布差异明显, 如 1960-2008 年, 东北地区 $E T_{0}$ 的基本特征为南多北
少, 且随着纬度的增加 $E T_{0}$ 递减特征明显 ${ }^{[2,3]}$ 。19612003 年, 松嫩平原 $E T_{0}$ 在 $(330 \sim 860) \mathrm{mm} / \mathrm{a}$ 之间, 空间 上总体表现为西南高、四周低的环带状分布特征 ${ }^{[4]}$ 。 1961-2010年, 辽河三角洲地区 $E T_{0}$ 介于(950 1045) $\mathrm{mm} / \mathrm{a}$, 水平分带性明显, 表现为自东南向西北递增 的分布特征 ${ }^{[5]}$ 。1960-2011 年, 西北五省 $E T_{0}$ 介于 (675 2282) mm/a , 空间分布差异显著 ${ }^{[6]}$ 。1960-2010 年, 甘肃地区 $E T_{0}$ 介于 $(772 \sim 1105) \mathrm{mm} / \mathrm{a}$, 表现为自北 向南递减 ${ }^{[7,8]}$ 。1959-2008 年, 渭河流域 $E T_{0}$ 在 $(779 \sim$ $1018) \mathrm{mm} / \mathrm{a}$ 之间,空间分布总体趋势为东高西低、北 高南低, 由东北向西南递减, 并且夏季最高, 其次是 春季、秋季和冬季 ${ }^{[9]}$ 。1961-2009年, 西藏雅鲁藏布 江中游地区 $E T_{0}$ 均值在 $1190 \mathrm{~mm} / \mathrm{a}$ 以上, 且自西向东 递增 ${ }^{[10]}$ 。1961-2012 年, 黄河流域 $E T_{0}$ 在 $(964 \sim 1037)$ $\mathrm{mm} / \mathrm{a}$ 之间, 上游较高, 中游较低 ${ }^{[11]} 。 1961-2011$ 年, 长江流域 $E T_{0}$ 在 $(456 \sim 760) \mathrm{mm} / \mathrm{a}$ 之间, 整体呈现自

收稿日期: 2017-01-03; 修订日期: 2017-03-15

基金项目: 国家自然科学基金(41371410)。

作者简介: 吴霞, 女, 黑龙江哈尔滨人, 硕士生, 研究方向为农业气象。E-mail : wuxia0428@163.com

通讯作者:王培娟, E-mail : wangpj@camscma.cn 
西向东先减小后增大的趋势 ${ }^{[12]}$ 。

中国不同区域 $E T_{0}$ 随时间的变化趋势也表现出 不同的特征。1961-2015年,中国东北地区 ${ }^{[2]}$ 、西北地 $区^{[6,13]} 、$ 西藏地区 ${ }^{[14-17]}$ 、黄土高原地区 ${ }^{[7]} 、$ 喀什格尔河流 域 ${ }^{[18]}$ 、石羊河流域 ${ }^{[19]} 、$ 淮河流域 ${ }^{[20]}$ 、黄河下游地区 ${ }^{[11]}$ 、 长江流域 ${ }^{[21]}$ 等地的 $E T_{0}$ 大多呈减小趋势; 但是在洮

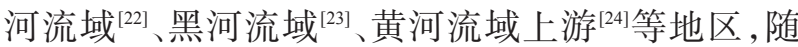
着时间的变化, $E T_{0}$ 则呈增加趋势。高歌等对 19562000 年中国及十大流域的研究得出,除松花江流域 外,全国绝大多数流域年和四季的 $E T_{0}$ 均呈现减小 趋势,南方各流域(西南诸河流域除外)年和夏季 $E T_{0}$ 减小趋势尤其明显 ${ }^{[25]}$ 。

关于 $E T_{0}$ 的变化成因方面,研究发现不同地区 $E T_{0}$ 的主导影响因子不同。Peterson等、Chattopadhyay等和 Bandyopadhyay等对美国、前苏联和印度 等地区 $E T_{0}$ 的研究中发现, 北半球相对湿度的增加 及辐射的减少是导致这些地区 $E T_{0}$ 下降的主要原 因 ${ }^{[26-28]}$ 。Roderick等对澳大利亚和新西兰地区的研 究认为 $E T_{0}$ 的减少是由南半球云量和气溶胶浓度的 增加引起的 ${ }^{[2]]}$ 。而 Eslamian 等认为伊朗 $E T_{0}$ 最敏感 的气候因子为气温和相对湿度 ${ }^{[30]}$ 。Hupet 等认为比 利时 $E T_{0}$ 最敏感的气候因子为最高气温 ${ }^{[31]}$ 。Thomas 对 1954-1993 年中国 $E T_{0}$ 的研究得出: 中国 $35^{\circ} \mathrm{N}$ 以 南 $E T_{0}$ 的主要影响因子为日照时数,这条线以北的 中国中部、东北部和西部分别受相对湿度、最高温 度和风速的影响最大 ${ }^{[32]}$ 。高歌等对 1956-2000 年中 国及十大流域的研究得出, 这 45 年日照时数和/或 风速的明显减少/减弱可能是导致大多数地区 $E T_{0}$ 减少的主要原因 ${ }^{[25]}$ 。Zhang 等、Xu等、尹云鹤等、王 亚平等、谢贤群等对中国 $E T_{0}$ 的研究表明,在北方地 区、青藏高原和长江流域等局部地区, $E T_{0}$ 的下降主 要是由于太阳辐射和风速的减小引起的 ${ }^{[17,21,33-35]}$ 。 曹雯等研究认为中国西北地区春、夏、秋三季 $E T_{0}$ 变 化的首要主导因子是风速,而冬季的首要主导因子 是气温 ${ }^{[13]}$ 。杨林山等研究得出洮河流域 $E T_{0}$ 最敏 感的气候因子为净辐射 ${ }^{[2]}$ 。刘昌明等研究得出中 国 $E T_{0}$ 对最高气温和太阳辐射最为敏感的月份是 7 月, 对最低气温、风速和水汽压最为敏感的月份是 1 月[36]。

目前关于潜在蒸散的研究主要集中在 2000 以
前, 对 2000 年后及 1961-2015 年整体时空变化趋势 及变化成因的研究有所不足。本文以中国 552 个气 象站点的资料和地理信息资料为基础, 利用 Penman-Monteith 公式,计算全国尺度 1961-2015 年 逐日潜在蒸散,分别从年、季节和年代际尺度, 分析 全国和各干湿气候区潜在蒸散时空变化特征及其 变化成因, 以期为中国干旱监测和干湿气候区划提 供基础数据。

\section{2 数据来源与研究方法}

\section{1 数据来源}

本研究收集了中国 560个气象站点 1961-2015 年的逐日降水、最高气温、最低气温、平均气温、相 对湿度、水汽压、 $10 \mathrm{~m}$ 平均风速和日照时数等数据, 资料来源于中国气象局气象数据网 ${ }^{[3]}$ 。经过数据质 量及有效性检查后,䇥选出数据较齐全的 552 个气 象站点(图 1), 对其中个别缺测数据, 采用该日相邻 两天该要素的平均值替代。

\section{2 研究方法}

\subsection{1 气候区划分标准}

根据目前普遍采用的降水量与气候区划分标 准(表 1$)^{[38]}$, 将全国分为 4 个区 (图 1, 见第967页)。

\section{表 1 降水量与气候区划分标准}

Table 1 The climatic regions based on classification criteria of rainfall

\begin{tabular}{ccccc}
\hline 干湿区带 & 干旱区 & 半干旱区 & 半湿润区 & 湿润区 \\
\hline 年降水量 $/ \mathrm{mm}$ & $<200$ & $200 \sim 400$ & $400 \sim 800$ & $\geqslant 800$ \\
\hline
\end{tabular}

2.2.2 潜在蒸散

采用 Penman-Monteith(P-M)方法 ${ }^{[1]}$ 计算潜在蒸 散 $E T_{0}$ :

$$
E T_{o}=\frac{0.408 \Delta\left(R_{n}-G\right)+\gamma \frac{900}{T+273} U_{2}\left(e_{s}-e_{a}\right)}{\Delta+\gamma\left(1+0.34 U_{2}\right)}
$$

式中 $E T_{o}$ 为潜在蒸散量 $(\mathrm{mm} / \mathrm{d}) ; \Delta$ 为饱和水汽压-温 度曲线的斜率 $\left(\mathrm{kPa} /{ }^{\circ} \mathrm{C}\right) ; R_{n}$ 为地表净辐射 $\left(\mathrm{MJ} /\left(\mathrm{m}^{2}\right.\right.$. d)); $G$ 为土壤热通量 $\left(\mathrm{MJ} /\left(\mathrm{m}^{2} \cdot \mathrm{d}\right)\right)$, 在逐日或 10 天 尺度上计算 $E T_{0}$ 时,土壤热通量相对较小,可以忽 略不计; $T$ 为日平均气温 $\left({ }^{\circ} \mathrm{C}\right) ; U_{2}$ 为 $2 \mathrm{~m}$ 高处风速 $(\mathrm{m} / \mathrm{s}) ; e_{s}$ 为饱和水汽压 $(\mathrm{kPa}) ; e_{a}$ 为实际水汽压 $(\mathrm{kPa}) ; \gamma$ 为干湿表常数 $\left(\mathrm{kPa} /{ }^{\circ} \mathrm{C}\right)$ 。

气象台站观测的 $10 \mathrm{~m}$ 高处的平均风速可用 $\mathrm{FAO}$ 推荐公式转换为 $2 \mathrm{~m}$ 高处的平均风速 ${ }^{[12]}$ : 


$$
U_{2}=\frac{4.87 U_{10}}{\ln (67.8 \times 10-5.42)}
$$

式中 $U_{10}$ 为 $10 \mathrm{~m}$ 高度处风速观测值 $(\mathrm{m} / \mathrm{s})$ 。

季节 (3-5 月为春季, 6-8 月为夏季, 9-11 月为秋 季, 12 -翌年 2 月份为冬季) 和年潜在蒸散为相应时 段 $E T_{0}$ 之和。

\subsection{3 反距离权重插值}

反距离权重 (Interse Distrance Weighted, IDW) 算法 ${ }^{[39]}$ 以插值点与样本点间的距离为权重进行加权 平均, 离插值点越近的样本点赋予的权重越大。该 方法具有算法简单、普适性更强的优点,被广泛应 用于各行业领域的空间分析与制图 ${ }^{[40]}$ 。本文使用该 插值方法仅是为了得到 $E T_{0}$ 的空间分布图, 后续具 体分析仍是在站点数据的基础上进行的,因此后文 省略了插值结果的精度评价部分。

\subsection{4 变化趋势分析}

利用最小二乘法 ${ }^{[41]}$ 构建年平均潜在蒸散与时间 的一元线性回归方程,用于分析中国 1961-2015 年 潜在蒸散线性变化趋势。方程的线性拟合斜率 $k$ 表示年平均潜在蒸散的变化趋势, 即正值表示年平 均潜在蒸散呈增加趋势, 负值表示减少趋势。

\subsubsection{Mann-Kendall 突变检验}

Mann-Kendall 方法 ${ }^{[42]}$ (以下简称 M-K 方法) 是 一种非参数统计检验方法, 是气象学和气候学中常 用的一种突变点检验方法。本文中显著性水平使 用 $\alpha=0.05$, 临界值 $u_{0.05}= \pm 1.96$, 将计算的 $U F_{k}$ 和 $U B_{k}$ 及显著水平临界线 ( 2 条直线) 画到一张图上。 若 $U F_{k}$ 的值大于 0 , 则表明序列呈上升趋势, 小于 0 则表明呈下降趋势。当它们超过临界直线时, 表明 上升或下降趋势显著。如果 $U F_{k}$ 和 $U B_{k}$ 两条曲线 出现交点, 且交点在临界线之间,那么交点对应的 时刻便是突变开始的时间。

\subsection{6 偏相关检验}

偏相关系数 ${ }^{[4]}$ 是多元回归分析中,在消除其他 变量影响的条件下,计算的某两个变量之间的相关 系数。本文采用 MATLAB 软件对中国 1961-2015 年各气象站点潜在蒸散和气象因子年平均值进行 偏相关检验分析。

\section{3 结果与分析}

\section{1 干湿气候分区}

根据全国 552个气象站点 1961-2015 年的逐日
降水数据,计算研究时段各站点年降水量平均值, 使用 ArcGIS 软件,利用 IDW 方法进行空间插值(插 值精度为 $\left.0.05^{\circ} \times 0.05^{\circ}\right)$,并提取年降水量等值线, 根 据表 1 将全国划分为 4 个区, 自西北至东南依次为 干旱区、半干旱区、半湿润区和湿润区 (图 1), 各分 区内的站点数量如表 2 所示。

\section{表 2 不同气候区内站点数量}

Table 2 The number of meteorological stations in different climatic regions

\begin{tabular}{lccccc}
\hline 干湿区带 & 干旱区 & 半干旱区 & 半湿润区 & 湿润区 & 全国 \\
\hline 站点数/个 & 73 & 67 & 172 & 240 & 552 \\
所占比例 $/ \%$ & 13 & 12 & 31 & 44 & 100 \\
\hline
\end{tabular}

\section{2 中国 1961-2015 年潜在蒸散空间分布特征}

3.2.1 年平均潜在蒸散空间分布特征

1961-2015 年, 中国年平均 $E T_{0}$ 为 $621 \sim 1733 \mathrm{~mm}$, 平均值为 $1043 \mathrm{~mm}$, 整体上呈现出南部和西北地区 高、东北和中部地区低的空间分布格局(图2)。ET 高值区主要分布在内蒙古自治区西部、甘肃省西北 部、新疆维吾尔自治区东南部、云南省中南部及南 部沿海地区, 大致为 1200 1733mm, 其中最高值出 现在内蒙古西部拐子湖地区, 约 $1733 \mathrm{~mm} ; E T_{0}$ 低值 区主要包括中国东北部、中西部 (四川盆地、青海省 中西部及东南部、甘肃省和重庆市南部、贵州省北 部) 及长江和黄河中上游地区等, 年平均 $E T_{0}$ 大致为 $621 ~ 900 \mathrm{~mm}$, 其中最低值出现在中国最北部漠河地 区, 约 $621 \mathrm{~mm}$; 其余地区 $E T_{0}$ 为 $900 \sim 1200 \mathrm{~mm}$ 。

从四个干湿气候分区的年平均 $E T_{0}$ 来看, 干旱 区最高, 达到 $1164 \mathrm{~mm}$; 湿润区和半干旱区居中, 分 别为 $1067 \mathrm{~mm}$ 和 $1042 \mathrm{~mm}$; 半湿润区最低,在 $960 \mathrm{~mm}$ 以下。高歌等对中国 2000 年以前的研究结果也显 示湿润区 $E T_{0}$ 略高于半湿润区 ${ }^{[25]}$ 。干旱区 $E T_{0}$ 一般 都高于 $1050 \mathrm{~mm}$, 其中中部及东部的沙漠、荒漠区 $E T_{0}$ 较高; 半干旱区 $E T_{0}$ 一般在 750 1050mm, 其中中 西部及东北部值较低; 半湿润区 $E T_{0}$ 一般低于 $1050 \mathrm{~mm}$ ，中西部及东北部地区值较低，低于 $900 \mathrm{~mm}$, 东北地区北部低于 $750 \mathrm{~mm}$; 湿润区 $E T_{0}$ 一般 为 750 1350mm, 其中云南中东部及南部沿海地区 值较高, 甚至超过 $1350 \mathrm{~mm}$, 中北部地区值较低。由 此可见, 1961-2015 年, 中国 $E T_{0}$ 高值区主要分布在 干旱区的中部和东部及湿润区的南部,低值区主要 分布在半干旱区的中西部及东北部、半湿润区的中 


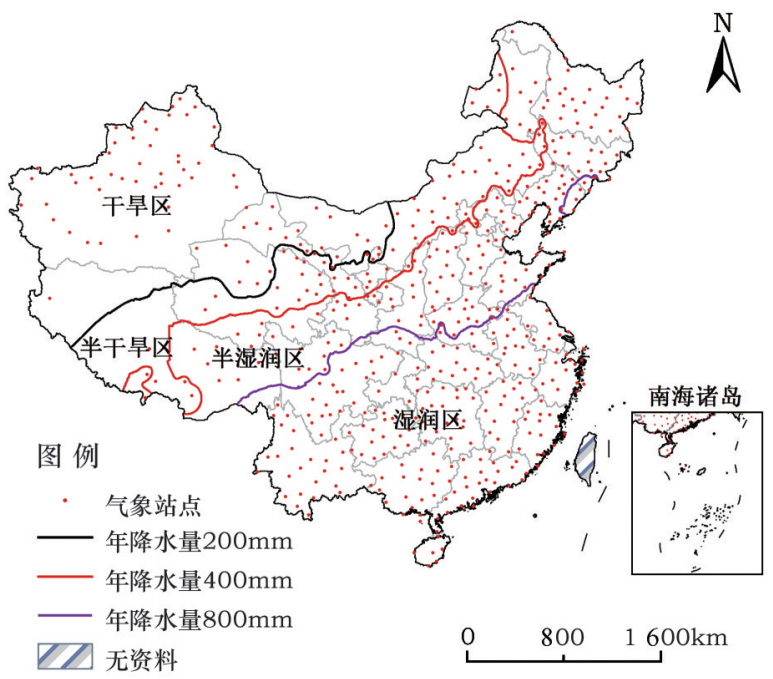

图 1 中国气象站点空间分布及气候分区

Figure 1 The spatial distribution of meteorological stations and its climatic regions in China

西部及东北部和湿润区的中北部地区。

3.2.2 季节平均潜在蒸散空间分布特征

全国范围内, 夏季的 $E T_{0}$ 平均值最高, 为 $410 \mathrm{~mm}$, 其次是春季 $309 \mathrm{~mm}$ 和秋季 $216 \mathrm{~mm}$, 冬季最 低为 $108 \mathrm{~mm}$, 分别占全年的 $39 \%, 30 \%, 21 \%$ 和 $10 \%$ (图 3)。夏季的 $E T_{0}$ 最高值出现在新疆阿拉山口,为 $836 \mathrm{~mm}$; 冬季的 $E T_{0}$ 最低值出现在内蒙古额尔古纳 右旗, 为 $8.7 \mathrm{~mm}$ 。

春季, 从干旱区到湿润区, $E T_{0}$ 整体呈现减少趋 势:干旱区北部、西部和南部部分地区 $E T_{0}$ 较低,一 般为 300 350mm, 部分地区低于 $300 \mathrm{~mm}$, 其余地区 一般高于 $350 \mathrm{~mm}$, 其中, 中部及东部部分地区高于 $450 \mathrm{~mm}$; 半干旱区、半湿润区和湿润区一般分别为 $250 \sim 400 \mathrm{~mm} 、 250 \sim 350 \mathrm{~mm}$ 和低于 $300 \mathrm{~mm}$; 其中, 湿 润区中部值低于 $250 \mathrm{~mm}$, 而西南部值较大, 部分地 区超过 $400 \mathrm{~mm}$ 。

夏季, $E T_{0}$ 表现为从北到南、自中部向东北和西 南逐渐减小的趋势, 具体为:干旱区 $E T_{0}$ 较高,一般 高于 $450 \mathrm{~mm}$, 中北部和东部地区高于 $550 \mathrm{~mm}$; 半干 旱区东北部、半湿润区中部及湿润区东部 $E T_{0}$ 较高, 一般为 400 500mm, 其中半干旱区中北部甚至达到 $550 \sim 600 \mathrm{~mm}$; 其余地区 $E T_{0}$ 较低, 部分地区低于 $400 \mathrm{~mm}$ 。

秋季, $E T_{0}$ 表现为自西北-东南向中部减小的趋

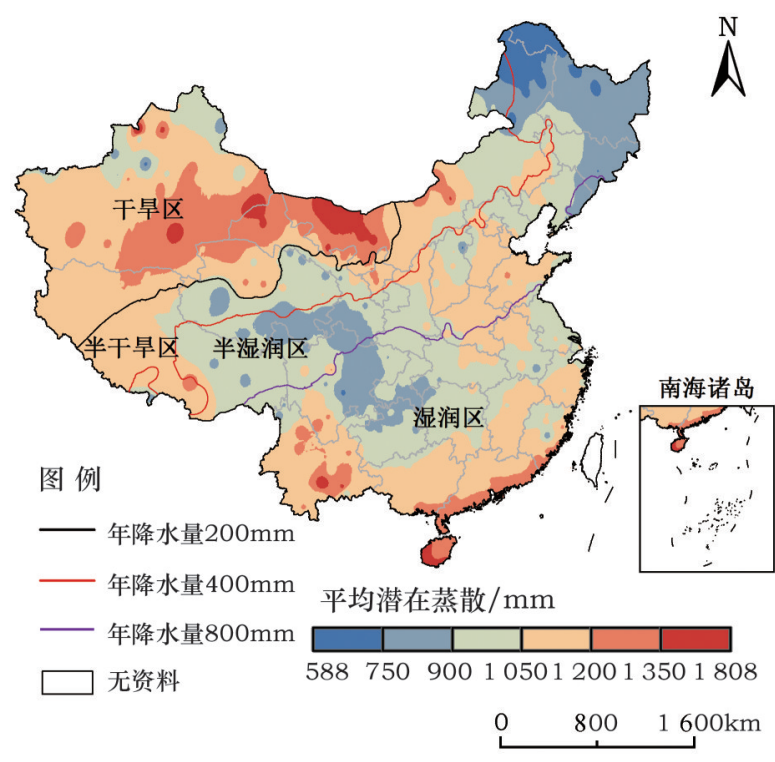

图 2 潜在蒸散空间分布

Figure 2 The spatial distribution of annual average potential evapotranspiration

势。干旱区除北部小部分区域 $E T_{0}$ 低于 $200 \mathrm{~mm}$ 外, 其余大部分地区都高于 $250 \mathrm{~mm}$; 半干旱区中部及东 北部地区 $E T_{0}$ 较低, 低于 $200 \mathrm{~mm}$, 其余地区一般为 200 250mm; 半湿润区中部及东北部地区 $E T_{0}$ 较低, 低于 $200 \mathrm{~mm}$, 东北部分地区甚至低于 $150 \mathrm{~mm}$, 其余 地区在 200 250mm; 湿润区 $E T_{0}$ 自西北向东南呈增 加趋势, 中北部地区低于 $200 \mathrm{~mm}$, 东南部地区高于 $300 \mathrm{~mm}$, 其余地区一般为 $200 \sim 300 \mathrm{~mm}$ 。

冬季, $E T_{0}$ 自北向南呈现增加趋势。干旱区、半 干旱区中部和北部、半湿润区东北部和中部部分地 区、湿润区中北部部分地区 $E T_{0}$ 几乎全部低于 $100 \mathrm{~mm}$; 湿润区西南部及南部地区 $E T_{0}$ 高于 $200 \mathrm{~mm}$; 其余地区一般为 $100 \sim 200 \mathrm{~mm}$ 。中国 $E T_{0}$ 在各季节中 的分布特征与高歌等 ${ }^{[43]}$ 针对中国十大流域的研究结 果趋于一致。

综合来看,干旱区的季节间 $E T_{0}$ 变化最大,其次 是半干旱区东北部、半湿润区中北部和湿润区西部 地区。

3.2.3 年代际平均潜在蒸散空间分布特征

从 1961-2015 年各年代际 $E T_{0}$ 的空间分布图看 (图 4, 见第969页),各干湿气候区的 $E T_{0}$ 在各年代 际的变化不大。从区域上看,中国西北部在 20 世纪 60 年代和 70 年代 $E T_{0}$ 高于 $1200 \mathrm{~mm}$ 的范围 (红色区 


\section{a.春季}

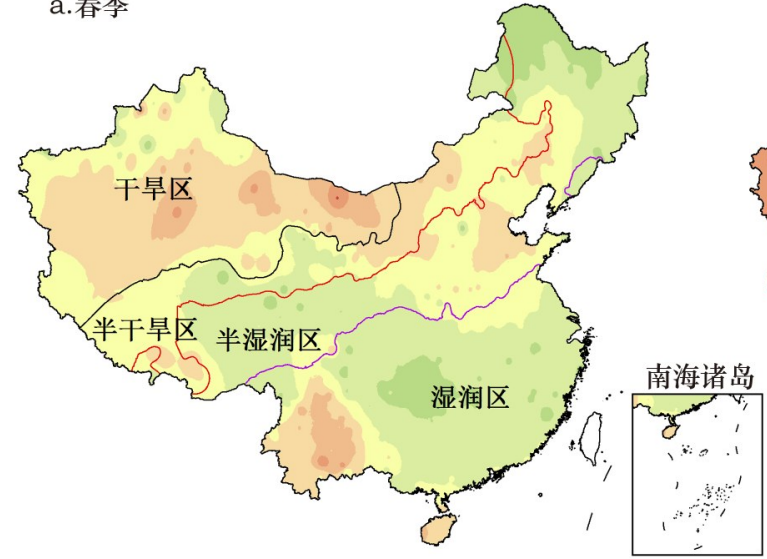

\section{b.夏季}



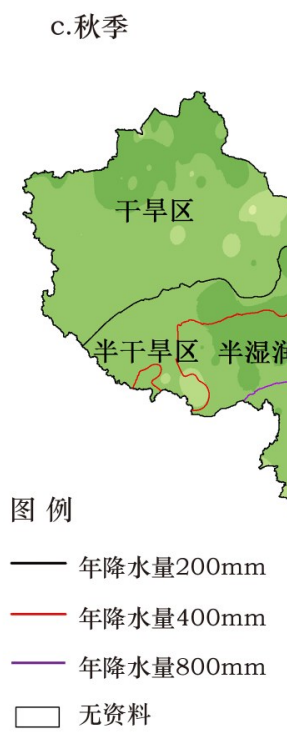

b.冬季

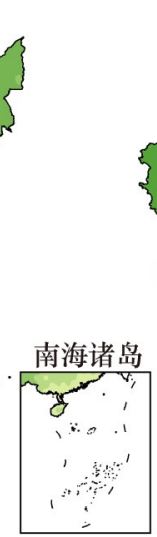

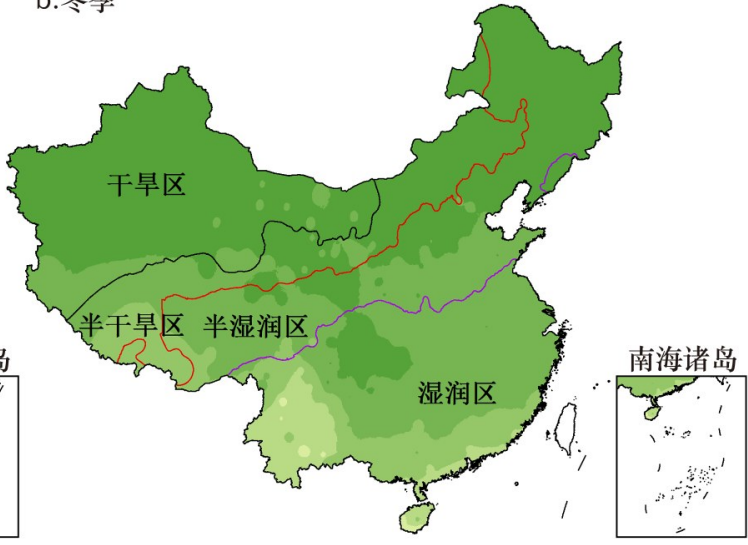

平均潜在蒸散 $/ \mathrm{mm}$

$0 \quad 100150200250300350400450500550600840$



图 3 季节平均潜在蒸散空间分布

Figure 3 The spatial distribution of seasonal average potential evapotranspiration

域)较大,之后开始缩小,到 2000 年后范围又略有扩 大,但仍小于 70 年代; 西南部 $E T_{0}$ 高于 $1200 \mathrm{~mm}$ 的范 围在 20 世纪 60-90 年代较小, 2000 年之后范围扩 大。长江和黄河中上游地区在 20 世纪 60-70年代 $E T_{0}$ 低于 $900 \mathrm{~mm}$ 的范围(蓝色区域)较小,之后开始 扩大, 2000 年后范围显著缩小; 长江下游地区 20 世 纪 60 年代 $E T_{0}$ 较高, 之后逐渐减小。

各年代全国平均 $E T_{0}$ 分别为 $1063 \mathrm{~mm} 、 1058 \mathrm{~mm}$ 、 $1025 \mathrm{~mm} 、 1024 \mathrm{~mm} 、 1045 \mathrm{~mm}$ 和 $1041 \mathrm{~mm}$; 与 1961 2015 年平均值的差值分别为 $20 \mathrm{~mm} 、 15 \mathrm{~mm} 、-18 \mathrm{~mm}$ 、 $-19 \mathrm{~mm} 、 2 \mathrm{~mm}$ 和 $-2 \mathrm{~mm}$ 。各年代内, 干旱区 $E T_{0}$ 均为 最高值, 其次是湿润区, 其均值高于全国平均值; 半
干旱区次低,半湿润区最低。通过对比,本文对 20

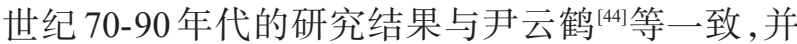
进一步对 2001-2015年进行了分析。

\section{3 中国 1961-2015 年潜在蒸散时间变化趋势}

\subsection{1 全国年平均潜在蒸散时间变化趋势}

1961- 2015 年, 整体上中国年平均 $E T_{0}$ 以 $0.52 \mathrm{~mm} / \mathrm{a}$ 的速率减少, 55 年共减少 $28.6 \mathrm{~mm}$, 相对变 化量为 2.5\% (图 5, 见第 970 页), 减少趋势通过了 0.01 的信度检验。高歌等、尹云鹤等、刘昌明等的 研究也得出 90 年代以前 $E T_{0}$ 呈下降趋势, 但图 5 显 示 90 年代以后 $E T_{0}$ 存在上升趋势 ${ }^{[25,33,36]}$ 。

对近几个年代 $E T_{0}$ 分别做线性回归 (表 3 , 见第 
a. $1960 \mathrm{~s}$



b. $1970 \mathrm{~s}$

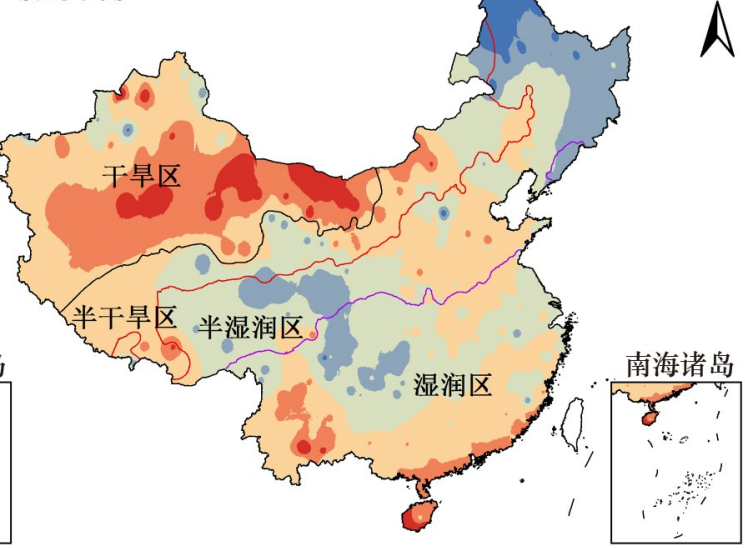

c. $1980 \mathrm{~s}$

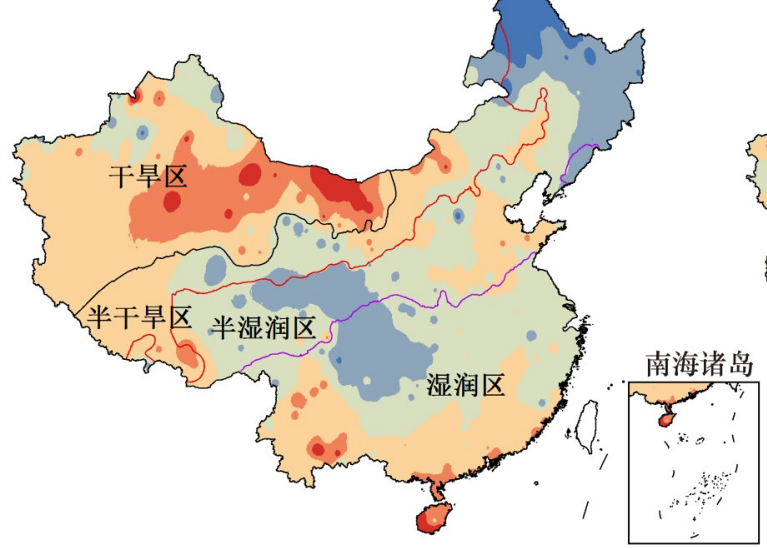

d.1990s

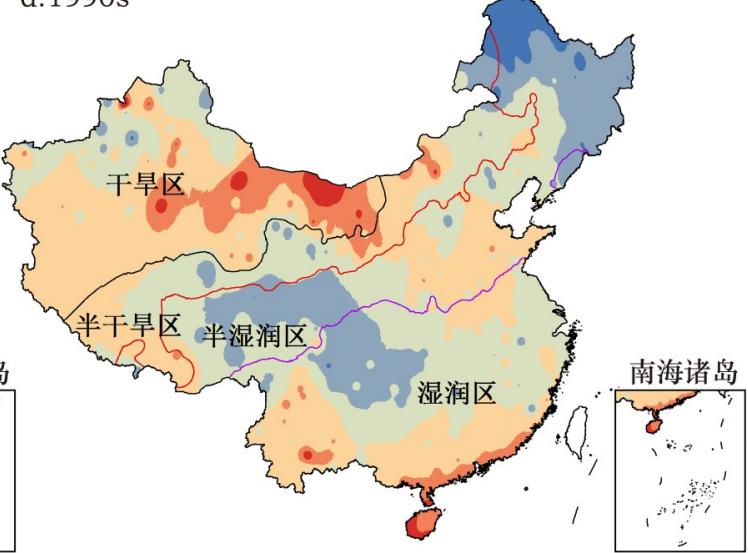

e.2000s

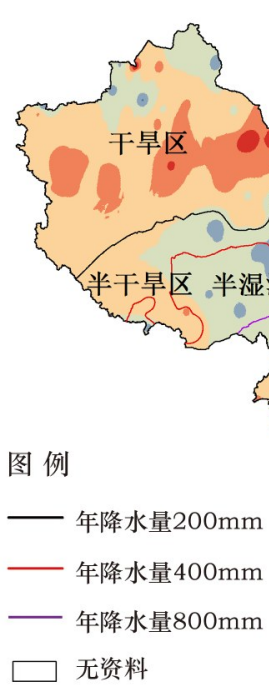

f.2011-2015年
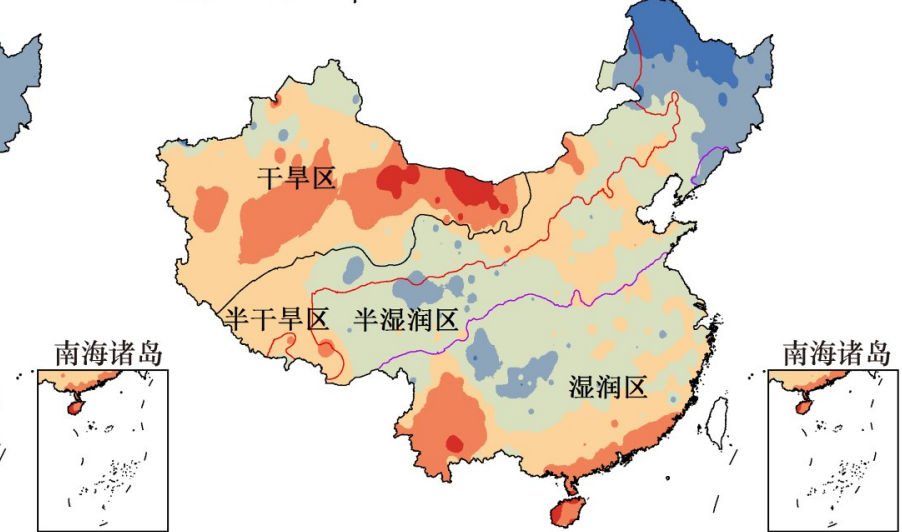

平均潜在蒸散 $/ \mathrm{mm}$

$\begin{array}{llllllllll}588 & 750 & 900 & 1050 & 1200 & 1350 & 1808\end{array}$

图 4 中国不同年代际平均潜在蒸散空间分布

Figure 4 The spatial distribution of average potential evapotranspiration in different decades in China 
表 3 各年代平均潜在蒸散变化趋势的回归系数及与潜在蒸散偏相关系数较高的前三个气象因子

Table 3 The regression coefficients of the change trend of average potential evapotranspiration and top 3

meteorological factors with higher partial correlation coefficients with potential vapotranspiration in different decades

\begin{tabular}{|c|c|c|c|c|c|c|}
\hline \multirow{2}{*}{$\begin{array}{c}\text { 年份 } \\
1961-1990 \text { 年 }\end{array}$} & \multirow{2}{*}{$\begin{array}{l}\text { 年代 } \\
1960 \mathrm{~s}\end{array}$} & \multicolumn{2}{|c|}{ 回归系数 } & \multicolumn{3}{|c|}{ 气象因子排序及其偏相关系数 } \\
\hline & & -0.969 & $-1.838 * *$ & 1 风速/** & 2 日照时数 $/ * *$ & 3 最高气温/** \\
\hline & $1970 \mathrm{~s}$ & -1.483 & & & & \\
\hline & $1980 \mathrm{~s}$ & -2.372 & & & & \\
\hline \multirow[t]{3}{*}{ 1991-2015年 } & $1990 \mathrm{~s}$ & 2.981 & $1.326 * *$ & 1 水汽压/** & 2 日照时数/** & 3 最低气温/** \\
\hline & $2000 \mathrm{~s}$ & 0.448 & & & & \\
\hline & 2011-2015年 & 2.585 & & & & \\
\hline
\end{tabular}

注:**和*分别表示通过 0.01 和 0.05 显著性检验。

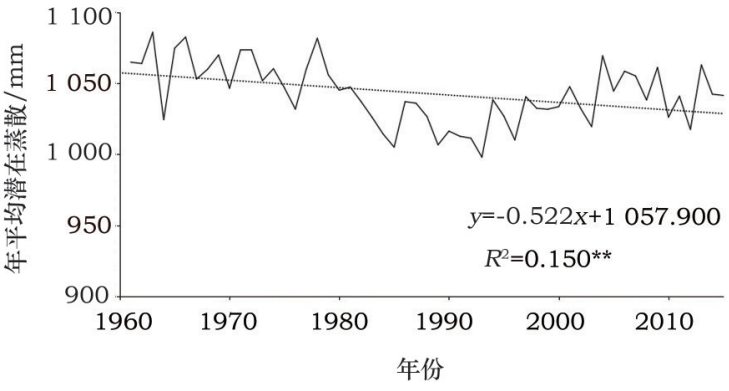

图 5 中国年平均潜在蒸散时间变化趋势

Figure 5 The temporal change trend of annual average potential evapotranspiration in China

970 页),发现全国范围内 20 世纪 60-80年代各年代 $E T_{0}$ 均呈下降趋势, 1961-1990年整体也呈下降趋势 且通过了 0.01 的显著性检验,该下降趋势主要受风 速、日照时数和最高气温影响较大, 与第 1 章节中各 位专家研究结果一致。90年代以后各年代 $E T_{0}$ 均呈 增加趋势, 1991-2015 年整体也呈上升趋势且通过 了 0.01 的显著性检验,该下降趋势主要受水汽压、 日照时数和最低气温的影响。从四个气候分区来 看,干旱区呈上升-下降-上升趋势,半干旱区、半湿 润区均呈上升-下降-上升-下降趋势,湿润区则呈下 降-上升趋势。干旱区 $E T_{0}$ 年代际变化幅度最大, 为 $88 \mathrm{~mm}$, 其次是湿润区 $47 \mathrm{~mm}$ 和半干旱区 $31 \mathrm{~mm}$, 半 湿润区最小 $30 \mathrm{~mm}$; 其中,干旱区和湿润区的 $E T_{0}$ 变 化幅度大于全国平均值 $39 \mathrm{~mm}$ 。

利用Mann-Kendall方法对中国 1961-2015 年年 平均 $E T_{0}$ 进行分析 (图 6), 由 $U F_{k}$ 曲线可见, 19612015 年, 中国 $E T_{0}$ 呈明显的下降趋势。并且 80 年代 开始这种趋势大大超过 0.05 临界线 $(-1.96)$ 甚至超 过 0.001 显著性水平 $\left(u_{0.001}= \pm 2.56\right)$, 表明中国 $E T_{0}$ 的

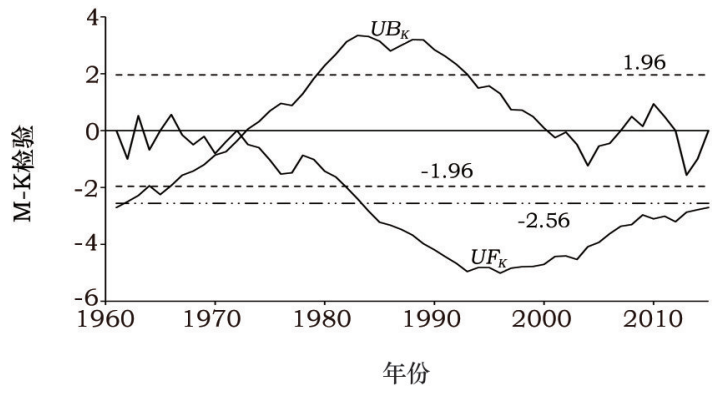

图 6 1961-2015 年年平均潜在蒸散 Mann-Kendall 检验结果

Figure 6 The statistical results of average annual potential evapotranspiration in Mann-Kendall test from 1961 to 2015

下降趋势是十分显著的。根据 $U F_{k}$ 和 $U B_{k}$ 曲线交点 的位置, 确定中国 $E T_{0}$ 在 1972 年存在下降趋势突然 增大的现象。然而, 对于 90 年代以后 $E T_{0}$ 的增大趋 势, M-K 检验并未检测到突变点。

3.3.2 各站点年平均潜在蒸散时间变化趋势分析

对全国 552 个站点 1961-2015 年年平均 $E T_{0}$ 进 行线性变化趋势分析,利用最小二乘法构建年平均 $E T_{0}$ 与时间的一元线性回归方程,方程的线性拟合 斜率 $k$ 表示年平均 $E T_{0}$ 的变化趋势, 其空间分布特征 如图 7a 所示。在全国 552 个站点中,有 334 个站点 $E T_{0}$ 呈减少趋势 $(k \leqslant 0)$, 占研究站点总数的 $60.5 \%$; 并 且 $-2<k \leqslant 0$ 的站点分布范围最为广泛, $k \leqslant-4$ 的站点数 最少。研究站点中有 218 个站点 $E T_{0}$ 呈增加趋势 $(k>$ $0)$, 占研究站点总数的 $39.5 \%$ 。其中, $0<k \leqslant 2$ 的站点 分布较为广泛, $k>2$ 的站点分布较为分散。

从整体上看 (图 7a), 干旱区 $k$ 值基本都为负值, 说明干旱区的大部分站点 $E T_{0}$ 呈减少趋势, 并且约 有一半区域 $k \leqslant-2$; 但在干早区西部和东部局部地 区 $E T_{0}$ 呈增加趋势, 部分地区 $k>2$ 。半干旱区和半 
a. 年平均潜在蒸散线性变化趋势 $(k)$

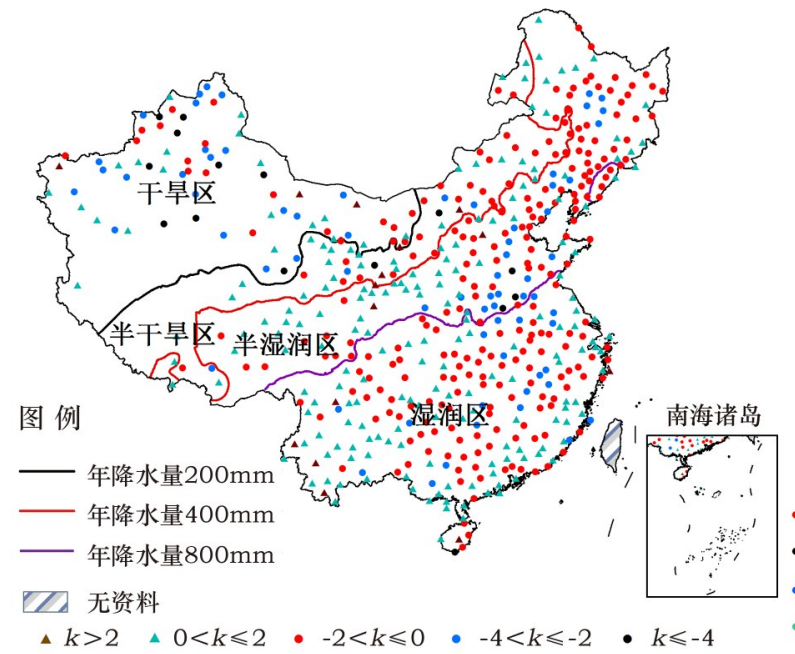

b. 年平均潜在蒸散线性变化趋势显著性检验结果

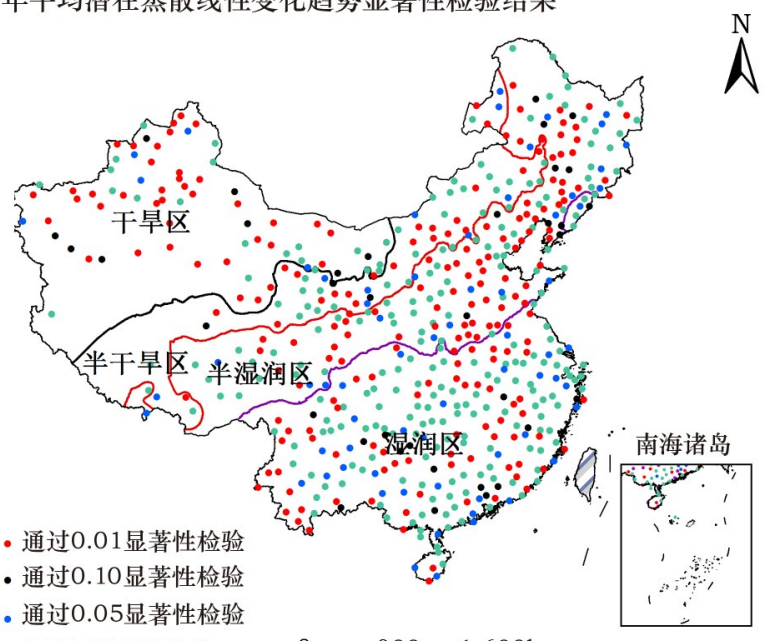

未通过显著性检验

$0 \quad 800 \quad 1600 \mathrm{~km}$

图 7 1961-2015 年各气象站点平均潜在蒸散线性变化趋势及显著性检验结果空间分布

Figure 7 The spatial distribution of the linear trend of annual average potential evapotranspiration and its significant test for each meteorological station from 1961 to 2015

湿润区 $k$ 值一般为 $-2<k \leqslant 2$, 且呈增加和减小趋势 的站点数量大致相等, 少部分地区 $k \leqslant-2$ 或 $k>2$ 。 湿润区大部分地区 $E T_{0}$ 呈减少趋势, 但是减少幅度 $(-2<k \leqslant 0)$ 多小于干旱区; 边界处部分地区 $E T_{0}$ 呈增 加趋势, 少部分地区 $k>2$ 。

对各站点 $E T_{0}$ 的线性变化趋势进行显著性检 验,空间分布特征如图 $7 \mathrm{~b}$ 所示。通过 0.1 信度检验 的站点共 311 个, 占研究站点总数的 $56 \%$; 这其中 $67 \%$ 的站点通过了 0.01 的信度检验。未通过显著性 检验站点有 241 个, 占研究站点总数的 $44 \%$ (表 4$)$ 。 4 个干湿气候分区中均分别有半数左右站点通过显 著性检验。

\section{4 中国 1961-2015 年潜在蒸散变化原因分析}

对中国 1961-2015 年各气象站点 $E T_{0}$ 和气象因 子年平均值进行偏相关检验分析, 得出 $E T_{0}$ 与各气
象因子偏相关系数绝对值大小依次为风速 $\left(p_{v}\right)$ 、日 照时数 $\left(p_{s n}\right)$ 、水汽压 $\left(p_{e a}\right)$ 、最高气温 $\left(p_{\text {max }}\right)$ 、相对湿度 $\left(p_{s}\right)$ 、最低气温 $\left(p_{\text {min }}\right)$ 和平均气温 $\left(p_{t}\right)$, 其偏相关系数 的全国平均值分别为 $0.816 、 0.723 、-0.246 、 0.228$ 、 $-0.213 、 0.119 、 0.041$ 。 $E T_{0}$ 与前三个因子 (风速、日照 时数和水汽压) 的偏相关系数空间分布见图 8 。在 全国范围内, 除零星地区 $p_{v}$ (图 $8 \mathrm{a}$ ) 较低外, 其余地 区一般高于 0.6 ; 其中,干旱区北部、半干旱区东北 部及中西部部分地区、半湿润区东北部及中西部部 分地区、湿润区中部和东部地区的 $p_{v}$ 在 $0.6 \sim 0.8$, 其 余地区高于 0.8 。全国范围内第一影响因素为风速 的站点有 294 个, 占全部站点的 $64 \%$, 主要分布在中 国北方地区、西南零星地区和东南部分地区; 第二 影响因素为风速的有 181 个站点, 占站点总数的 $33 \%$ 。 $p_{s n}$ (图 $8 \mathrm{~b}$ ) 呈现出由北向南逐渐增高的趋势;

表 4 各气候分区年平均潜在蒸散线性变化趋势显著性检验结果

Table 4 The significant test results of the linear trend of annual average potential evapotranspiration in different climatic regions

\begin{tabular}{|c|c|c|c|c|c|}
\hline \multirow{2}{*}{ 气候区 } & \multicolumn{3}{|c|}{ 通过显著性检验站点数/个 } & \multirow{2}{*}{$\begin{array}{c}\text { 通过显著性检验站 } \\
\text { 点总和 } / \text { 个 }\end{array}$} & \multirow{2}{*}{$\begin{array}{c}\text { 通过显著性检验站点占该 } \\
\text { 区总站点比例 } / \%\end{array}$} \\
\hline & 0.01 & 0.05 & 0.10 & & \\
\hline 干旱区 & 40 & 5 & 9 & 54 & 74 \\
\hline 半干旱区 & 24 & 8 & 2 & 34 & 51 \\
\hline 半湿润区 & 76 & 21 & 9 & 106 & 62 \\
\hline 湿润区 & 67 & 34 & 16 & 117 & 49 \\
\hline 全国 & 207 & 68 & 36 & 311 & 56 \\
\hline
\end{tabular}






b. 日照时数

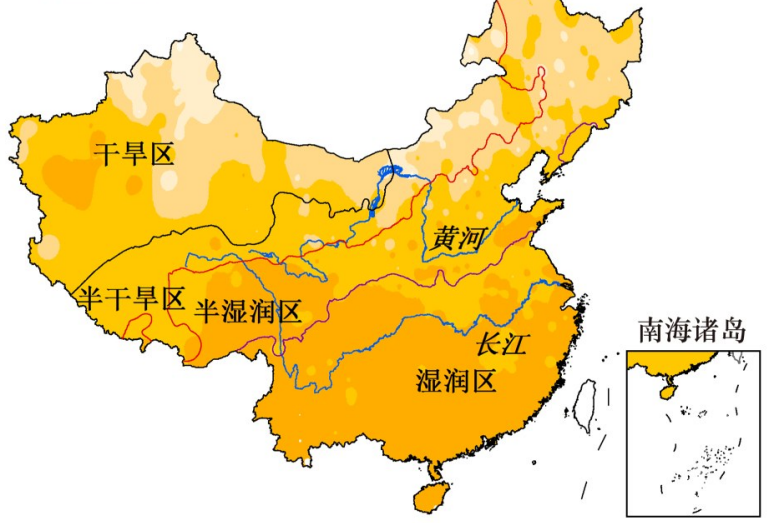

c.水汽压

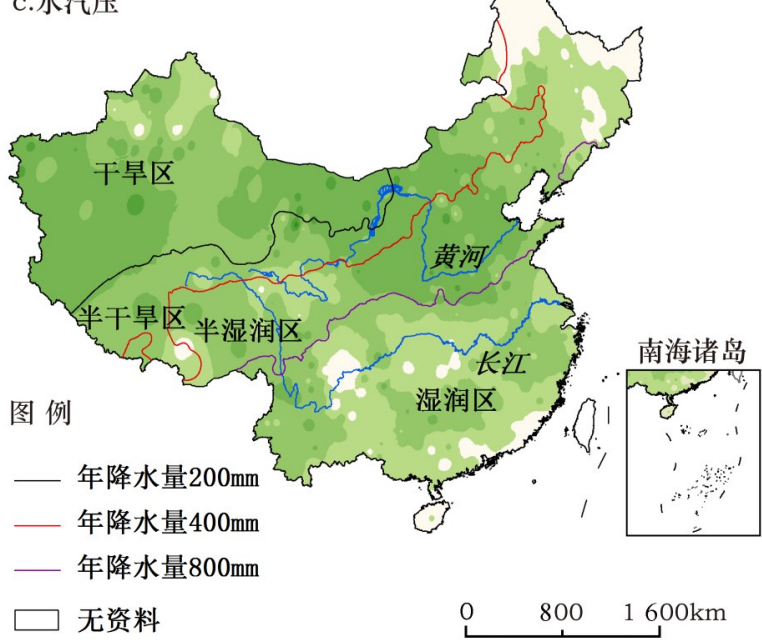

偏相关系数



图 8 各气象站点年平均潜在蒸散与前三个气象 因子偏相关系数

Figure 8 The partial correlation coefficients between annual average potential evapotranspiration and top 3 meteorological factors in China
其中,干旱区北部、半干旱区东北部和半湿润区东 北部部分地区 $p_{s n}$ 低于 0.4 ,干旱区中部和东部、半干 旱区东北部、半湿润区东北部 $p_{s n}$ 一般为 $0.4 \sim 0.6$,干 旱区西部部分地区、半湿润区西部及中部零星地 区、湿润区大部 $p_{s n}$ 高于 0.8 , 其余地区一般为 $0.6 \sim$ 0.8 。全国范围内第一影响因素为日照时数的站点 有 194 个, 占全部站点总数的 $35 \%$, 主要集中分布 在长江中下游地区、东北部分地区、西南地区南部 及东部和南部沿海地区; 第二影响因素为日照时数 的有 294 个站点,占站点总数的 $53 \%$ 。潜在蒸散与 水汽压的偏相关系数 $p_{e a}$ (图 8c), 除中国干旱区北 部、半干旱区及半湿润区的东北部和西部、湿润区 的部分地区为正值外,其余地区均为负值; 其中, 中 国西北和中北部地区、西南零星地区 $p_{e a}$ 相对较高, 绝对值一般高于 0.6 ; 个别零星地区绝对值高于 0.8 ; 干旱区北部、中国东北地区、半干旱区西部及 半湿润区西部部分地区、湿润区大部 $p_{e a}$ 较低, 绝对 值一般低于 0.2 。水汽压多为站点 $E T_{0}$ 的第二影响 因素, 共 28 个站点, 占总数的 $5 \%$, 主要集中分布在 内蒙古中部、陕西、山西及西藏的部分站点。

将每个站点与 $E T_{0}$ 偏相关系数最高的两个气象 因子进行综合分析(图9), 发现偏相关系数排在前 两位的气象因子中,第一影响因素为风速、第二影 响因素为日照时数的站点共有 294 个, 占总数的 $53 \%$ 以上, 主要分布在中国西南和东南部分地区、 长江流域以北; 第一影响因素为日照时数、其次为 风速的站点共有 177 个, 占总数的 $32 \%$, 主要分布 在中国长江流域、东北和西南零星地区、东南部分 地区; 水汽压对中国中北部地区和西北零星地区 (内蒙古中部、陕西、山西及西藏的部分站点) 的 $E T_{0}$ 影响较大, 且多为第二影响因素 (风速为第一影响 因素), 说明中国大部分地区 $E T_{0}$ 的变化与风速和日 照时数有关。该研究结果与第一节中列举的各位 专家的结果整体趋于一致, 但 Thomas $^{\left[{ }^{[3]}\right]}$ 的研究结 果认为中国东北地区 $E T_{0}$ 变化的主导因子为最高温 度, 本文研究认为是风速。

分析全国 1961-2015 年风速、日照时数和水汽 压的时间变化趋势 (图 10), 可知风速在 19 世纪 60 年代初期变化相对稳定, 在 60 年代末及 70 年代初 期处于较高水平,之后呈明显的减小趋势; 日照时 


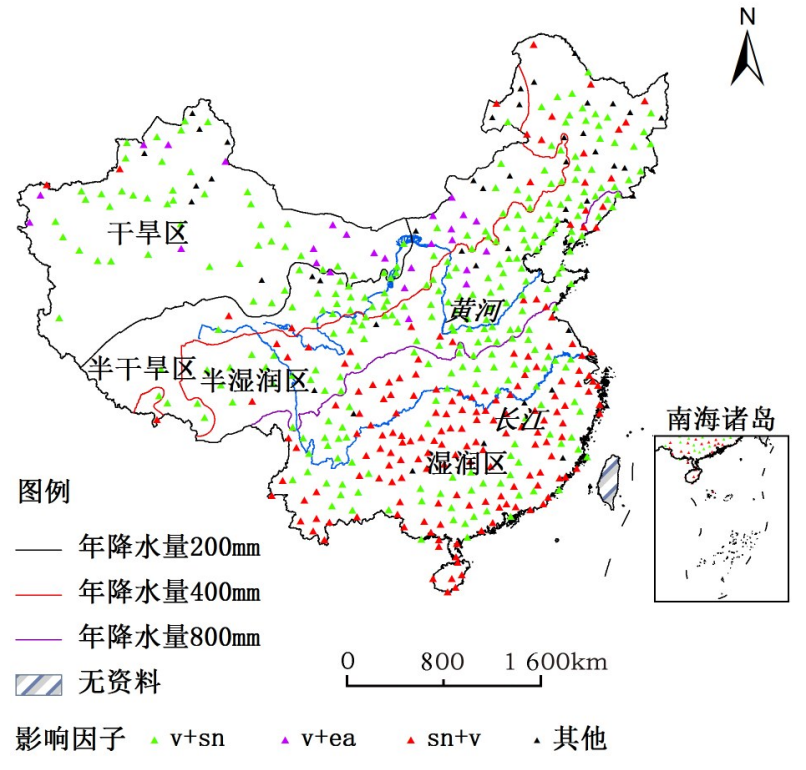

图 9 各气象站点与年平均潜在蒸散偏相关系数较高的 两个因子组合分布

Figure 9 The spatial distribution of meteorological factors with higher partial correlation coefficient between annual $E T_{0}$ and meteorological factors in China

注:图中“+”前的字母表示该站点与潜在蒸散偏相关系数最高的 气象因子, “+”后的字母表示该站点与潜在蒸散偏相关系数次高 的气象因子 ( $\mathrm{v}$ 为风速、 $\mathrm{sn}$ 为日照时数、ea为水汽压)。
数也呈减小趋势, 但较风速的减小趋势弱; 而水汽 压基本稳定, 呈微弱的增加趋势。前面分析可知, 风速和日照时数与 $E T_{0}$ 呈现正相关关系, 水汽压与 $E T_{0}$ 呈负相关关系, 因此, 风速的减小、日照时数的 降低和水汽压的微弱增加, 共同导致过去 55 年中国 $E T_{0}$ 整体上表现出减少的趋势; 而风速在 70 年代初 的明显减小趋势可能是引起中国年平均 $E T_{0}$ 在 1972 年存在下降速率突然增大现象的主要原因。

\section{4 结论与讨论}

以中国 1961-2015 年 552 个气象站点的逐日气 象数据及地理信息数据为基础, 利用 PenmanMonteith公式, 计算得到全国各站点逐日潜在蒸散, 根据降水量与气候区划分标准, 以中国近 55 年平均 降水量数据为依据, 将全国划分为四个气候分区: 即干早区、半干早区、半湿润区和湿润区, 对各气候 分区不同时段潜在蒸散进行统计, 分析中国 19612015 年潜在蒸散的时空变化特征及其变化成因, 得 到以下主要结论:

（1）1961-2015年, 中国 552个站点各站点 19612015 年 $E T_{0}$ 的平均值在 621 1733mm 之间, 表现出

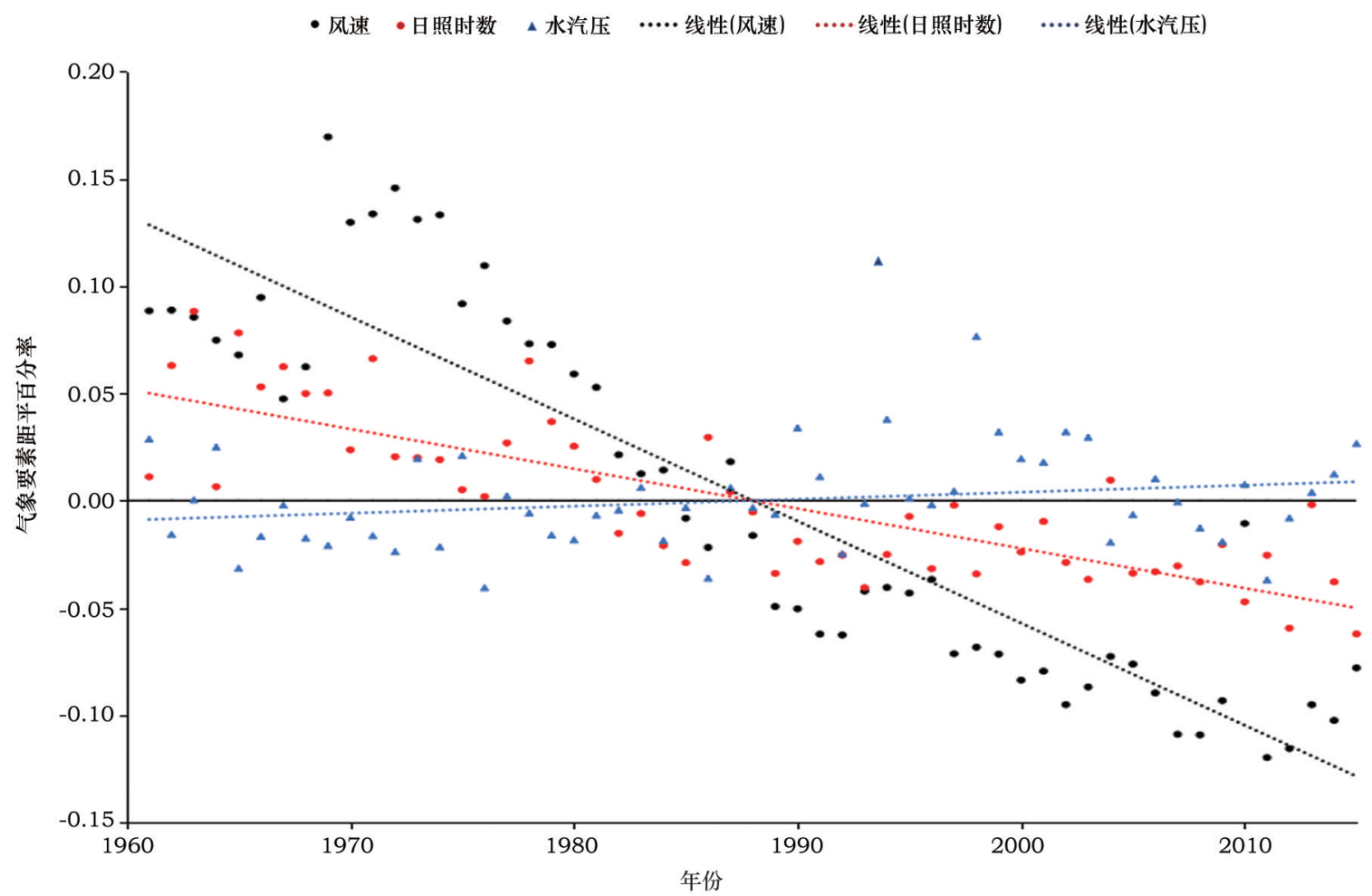

图 10 1961-2015 年中国风速、日照时数和水汽压随时间相对变化趋势

Figure 10 The relative change trend of wind speed, sunshine hour and vapor pressure in China from 1961 to 2015 
西北和南部地区高、东北和中部地区低的空间分布 格局, 其中高值区主要分布在干旱区中西部及湿润 区南部,低值区主要分布在半干旱区和半湿润区的 中西部及东北部、湿润区中北部地区。

(2) 全国范围内夏季 $E T_{0}$ 最高、春季和秋季次 之、冬季最低,分别占年平均 $E T_{0}$ 的 $39 \% 、 30 \% 、 21 \%$ 和 $10 \%$; 各季节 $E T_{0}$ 在空间分布上差异明显, 春季呈 自北向南逐渐减小的趋势,夏季为自北向南、自中 部向东北和西南逐渐减小的趋势,秋季则表现为自 西北-东南向中部减小的趋势, 冬季与春季相反, 呈 自北向南逐渐增大的趋势。近几个年代际,全国平 均 $E T_{0}$ 呈微弱的减小-增加趋势, $E T_{0}$ 变化幅度最大 的区域主要分布在内蒙古西部、新疆、长江流域及 黄河上游地区; 且在各年代际内, $E T_{0}$ 均表现为干旱 区最高、半干旱区和湿润区次之、半湿润区最低的 空间分布格局。

（3）1961-2015 年,整体上中国年平均 $E T_{0}$ 以 $0.52 \mathrm{~mm} / \mathrm{a}$ 的速率减少,干旱区和湿润区内大部分站 点年平均 $E T_{0}$ 呈减少趋势, 半干旱区和半湿润区呈 现增加和减少趋势的站点数则大致相等。MannKendall 方法的检验结果显示中国年平均 $E T_{0}$ 的下 降趋势在 1972 年存在下降速率突然增大的现象。 20 世纪 90 年代以后 $E T_{0}$ 有增加的趋势, 但是 $\mathrm{M}-\mathrm{K}$ 检 验并未检测到突变点。

(4) 中国 $85 \%$ 以上站点 $E T_{0}$ 的变化与风速和日 照时数相关, 1961-2015 年 $E T_{0}$ 呈减少趋势主要是风 速的减小、日照时数的降低和水汽压的微弱增加共 同作用的结果。 20 世纪 90 年代以后 $E T_{0}$ 的增加趋 势主要是由水汽压、日照时数和最低气温共同导 致的。

本文的计算结果是基于气象台站观测数据得 到的, 实际上气象台站与周边其他区域的土地利用 类型并不完全一致,导致基于气象台站观测数据计 算得到的 $E T_{0}$ 对周边区域的代表性存在一定的局限 性。但是在现有地面实测数据的条件下,仅能得到 这样的计算结果。后续研究中应进一步分析不同 土地利用格局对 $E T_{0}$ 的影响。

国际上通用的 $E T_{0}$ 计算过程中,地表辐射的计 算只考虑了日照时数,主要是该要素相对客观、定 量、可描述。然而,大气透明度和云量也是影响地
表辐射的关键要素,但是在目前的地面气象观测 中, 大气透明度并未列人常规观测要素中;云量虽 然有观测记录,但是该记录具有一定的主观性,且 相同的云量、不同的云状对地表辐射的影响程度不 同。因此上述两个影响地表辐射的要素在现有地 面观测条件下还不具备定量描述 $E T_{0}$ 的能力, 可作 为后续研究重点。

另外,在分析 $E T_{0}$ 变化趋势成因时,后续研究中 应考虑各因子间的相关性及多因子的综合效应, 以 明确 $E T_{0}$ 的主要影响因子。

\section{参考文献(References)：}

[1] Allen R G, Pereira L S, Raes D, et al. Crop Evapotranspiration: Guidelines for Computing Crop Water Requirements[R]. Rome: FAO Irrigation and Drainage Paper 56, 1998 .

[2] 陈莉, 方丽娟, 李帅. 东北地区生长季潜在蒸散量的变化特征 分析 [J]. 灾害学, 2010, 25(2): 92-96. [Chen L, Fang L J, Li S. Variation characteristics of potential evapotranspiration in growing season of crops in northeast China[J]. Journal of Catastrophology, 2010,25(2): 92-96.]

[3] 翟晴飞,敖雪,孙宝利, 等. 辽宁省 1981-2010年潜在蒸散量的 变化及生态需水分析 [J]. 中国农学通报, 2014, 30 (17): 228235. [Zhai Q F, Ao X, Sun B L, et al. The change of potential evapotranspiration from 1981 to 2010 and the analysis of ecological water demand[J]. Chinese Agricultural Science Bulletin, 2014,30(17):228-235.]

[4] 张永芳, 邓珺丽, 关德新, 等. 松嫩平原潜在蒸散量的时空变化 特征[J]. 应用生态学报, 2011, 22(7): 1702-1710. [Zhang Y F, Deng J L, Guan D X, et al. Spatiotemporal changes of potential evapotranspiration in Songnen Plain of Northeast China[J] Chinese Journal of Applied Ecology, 2011, 22(7): 1702-1710.]

[5] 王炳亮, 李国胜. 1961-2010 年辽河三角洲潜在蒸散时空变化 趋势 [J]. 西南大学学报 (自然科学版), 2014, 36(9): 154-162.

[Wang B L, Li G S. Spatial distribution and temporal trends in potential evapotranspiration $\left(E T_{0}\right)$ over Liaohe Delta in the period 1961 -2010[J]. Journal of Southwest University (Natural Science Edition), 2014, 36(9): 154-162.]

[6] 刘宪锋, 潘耀忠, 张锦水, 等. 1960-2011 年西北五省潜在蒸散 的时空变化 [J]. 应用生态学报, 2013, 24(9): 2564-2570. [Liu X F, Pan Y Z, Zhang J S, et al. Spatiotemporal variation patterns of potential evapotranspiration in five provinces of North-west China in 1960-2011[J]. Chinese Journal of Applied Ecology, 2013,24(9):2564-2570.] 
[7] 卓玛兰草,刘普幸,张亚宁, 等. 甘肃黄土高原区潜在蒸散量时 空变化与成因研究 [J]. 水土保持研究, 2012, 19 (1) : 70-75 [Zhuo M, Liu P X, Zhang Y N, et al. Study on temporal and spatial changes of the potential evapotranspiration and its impact factors in Loess Plateau of Gansu province[J]. Research of Soil and Water Conservation, 2012, 19(1): 70-75.]

[8] 卓玛兰草. 甘肃省 1960-2009 年不同气候区潜在蒸散量敏感性 分析研究 [D]. 兰州: 西北师范大学, 2012. [Zhuo M. Sensitivity of the Potential Evapotranspiration to Different Climatic Regions from 1960 to 2009 in Gansu Province [D]. Lanzhou: Northwest Normal University, 2012.]

[9] 左德鹏, 徐宗学, 程否, 等. 渭河流域潜在蒸散量时空变化及其 突变特征 [J]. 资源科学, 2011, 33(5): 975-982. [Zuo D P, Xu Z $\mathrm{X}$, Cheng L, et al. Spatial-temporal variations and mutations of potential evapotranspiration in the Weihe River Basin[J]. Resources Science, 2011,33(5):975-982.]

[10] 唐小萍, 罗礼洪, 卓玛, 等.气候变化对西藏雅鲁藏布江中游地 区潜在蒸散量的影响分析 [J]. 高原山地气象研究, 2011, 31 (3) : 49-53. [Tang X P, Luo L H, Zhuo M, et al. Impact analysis of climate change on potential evapotranspiration over midstream of Yarlung Zangbo River in Tibetan Plateau[J]. Plateau and Mountain Meteorology Research, 2011,31(3): 49-53.]

[11] 刘勤, 严昌荣, 赵彩霞, 等. 黄河流域日潜在蒸散量变化及气象 敏感要素分析[J]. 农业工程学报, 2014, 30(17): 157-166. [Liu Q, Yan C R, Zhao C X, et al. Changes of daily potential evapotranspiration and analysis of its sensitivity coefficients to key climatic variables in Yellow River Basin[J]. Transactions of the Chinese Society of Agricultural Engineering, 2014, 30 (17): 157-166.]

[12] 王琼, 张明军, 潘淑坤, 等. 长江流域潜在蒸散量时空变化特征 [J]. 生态学杂志, 2013, 32(5): 1292-1302. [Wang Q, Zhang M $\mathrm{J}$, Pan S K, et al. Spatiotemporal variation patterns of potential evapotranspiration in the Yangtze River Basin of China[J] Chinese Journal of Ecology, 2013, 32 (5): 1292-1302.]

[13] 曹雯, 申双和, 段春锋. 中国西北潜在蒸散时空演变特征及其 定量化成因 [J]. 生态学报, 2012, 32(11): 3394-3403. [Cao W, Shen S H, Duan C F. Temporal- spatial variations of potential evapotranspiration and quantification of the causes in Northwest China[J]. Acta Ecologica Sinica, 2012, 32 (11):3394-3403.]

[14] 杜军,李春, 拉巴,等. 西藏近 35 年地表湿润指数变化特征及其 影响因素 [J]. 气象学报, 2009, 67 (1): 158-164. [Du J, Li C, La $\mathrm{B}$, et al. Climatic change of terrestrial surface humid index and its impact factors over Tibet in recent 35 years[J]. Acta Meteorologica Sinica , 2009, 67 (1): 158-164.]

[15] 杜军, 胡军, 唐述君, 等. 西藏羊卓雍湖流域气候干湿状况分析 [J]. 生态学杂志, 2008, 27(8): 1379-1385. [Du J, Hu J, Tang S $\mathrm{J}$, et al. Analysis of climatic dry and wet conditions in Yamdok
Tso Lake Basin of Tibet[J]. Chinese Journal of Ecology, 2008, 27 (8): 1379-1385.]

[16] Chen S B, Liu Y F, Thomas A. Potential evapotranspiration trends and its spatial distributions on the Tibetan Plateau from 1961 to 2000[J]. Journal of Natural Resources, 2008, 23 (6): 990-1008.

[17] Zhang Y, Liu C, Tang Y, et al. Trends in pan evaporation and reference and actual evapotranspiration across the Tibetan Plateau[J]. Journal of Geophysical Research Atmospheres, 2007, 112(D12): 1103-1118.

[18] 加孜拉. 喀什噶尔河流域参考作物蒸散量变化趋势及其主要 影响因素分析[J]. 安徽农业科学, 2014, (25): 8866-8869. [Jia Z L. Kashgar River Basin reference crops evapotranspiration quantity change trend and its main influencing factors analysis [J]. Journal of Anhui Agriculture Science, 2014, (25) : 88668869.]

[19] 赵福年, 赵铭, 王莺, 等. 石羊河流域 1960-2009年参考蒸散量 与蒸发血蒸发量变化特征 [J]. 干旱气象, 2014, 32(4): 560568. [Zhao F N, Zhao M, Wang Y, et al. Variation characteristics of reference evapotranspiration and pan evaporation during 19602009 in Shiyang River Basin[J]. Journal of Arid Meteorology, 2014,32(4): 560-568.]

[20] 王晓东, 马晓群, 许芗, 等. 淮河流域参考作物蒸散量变化特征 及主要气象因子的贡献分析 $[J]$. 中国农业气象, 2013, 34(6): 661- 667. [Wang X D, Ma X Q, Xu Y, et al. Variation of reference crop evapotranspiration and contribution of main factors in the Huaihe Basin[J]. Chinese Journal of Agrometeoro$\log y, 2013,34(6): 661-667$.

[21] Xu C, Gong L, Jiang T, et al. Analysis of spatial distribution and temporal trend of reference evapotranspiration and pan evaporation in Changjiang (Yangtze River) catchment[J] Journal of Hydrology, 2006, 327(1-2): 81-93.

[22] 杨林山, 李常斌,王帅兵, 等. 洮河流域潜在蒸散发的气候敏感 性分析[J]. 农业工程学报, 2014, 30(11): 102-109. [Yang L S, Li C B, Wang S B, et al. Sensitive analysis of potentia evapotranspiration to key climatic factors in Taohe River Basin [J]. Transactions of the Chinese Society of Agricultural Engineering, 2014,30(11): 102-109.]

[23] 雒新萍, 王可丽, 江影, 等. 2000-2008 年黑河流域潜在蒸散量 的时空变化 [J]. 安徽农业科学, 2011, 39(25): 15737-15738 [Luo X P, Wang K L, Jiang H, et al. Analysis on temporalspatial variations of potential evapotranspiration in the Heihe River Basin during 2000-2008[J]. Journal of Anhui Agriculture Science, 2011, 39(25): 15737-15738.]

[24] 王亚俊, 李俊, 林忠辉, 等. 气候变化对黄河中上游地区潜在蒸 散影响的估算 [J]. 中国水土保持科学, 2013, 11(5): 48-56. [Wang Y J, Li J, Lin Z H, et al. Assessing the impacts of climate 
change on the potential evapotranspiration in the upper-middle reach of the Yellow River[J]. Science of Soil and Water Conservation, 2013, 11(5): 48-56.]

[25] 高歌,陈德亮, 任国玉, 等. 1956-2000年中国潜在蒸散量变化 趋势 [J]. 地理研究, 2006, 25(3): 378-387. [Gao G, Chen D L, Ren G Y, et al. Spatial and temporal variations and controlling factors of potential evapotranspiration in China: 1956-2000[J]. Journal of Geographical Sciences, 2006, 25(3): 378-387.]

[26] Peterson T C, Golubev V S, Groisman P Y. Evaporation losing its strength[J]. Nature, 1995,377(6551): 687-688.

[27] Chattopadhyay N, Hulme M. Evaporation and potential evapotranspiration in India under conditions of recent and future climate change[J]. Agricultural \& Forest Meteorology, 1997, 434 (1): 55-73.

[28] Bandyopadhyay A, Bhadra A, Raghuwanshi N S, et al. Temporal trends in estimates of reference evapotranspiration over India[J]. Journal of Hydrologic Engineering, 2014, 14(5): 508-515.

[29] Roderick M L, Farquhar G D. Changes in Australian pan evaporation from 1970 to 2002[J]. International Journal of Climatology, 2004, 24(9): 1077-1090.

[30] Eslamian S, Khordadi M J, Abedi-Koupai J. Effects of variations in climatic parameters on evapotranspiration in the arid and semiarid regions[J]. Global \& Planetary Change,2011,78(3-4):188-194.

[31] Hupet F, Vanclooster M. Effect of the sampling frequency of meteorological variables on the estimation of the reference evapotranspiration[J]. Journal of Hydrology, 2001, 243 (3-4) : 192-204.

[32] Thomas A. Spatial and temporal characteristics of potential evapotranspiration trends over China[J]. International Journal of Climatology, 2000, 20(4):381-396.

[33] 尹云鹤, 吴绍洪,戴尔阜. 1971-2008 年中国潜在蒸散时空演变 的归因 [J]. 科学通报, 2010,55(22): 2226-2234. [ Yin Y H, Wu S H, Dai E F. Determining factors in potential evapotranspiration changes over China in the period 1971-2008[J]. Chinese Science Bulletin, 2010, 55(22): 2226-2234.]

[34] 王亚平, 黄耀, 张稳. 中国东北三省 1960-2005 年地表干燥度 变化趋势 [J]. 地球科学进展, 2008,23(6): 619-627. [Wang Y P, Huang Y, Zhang W. Variation and tendency of surface aridity index from 1960 to 2005 in Three Provinces of Northeast China [J]. Advances in Earth Science, 2008, 23(6): 619-627.]

[35] 谢贤群,王菱. 中国北方近 50 年潜在蒸发的变化 [J]. 自然资源
学报, 2007, 22 (5) : 683-691. [Xie X Q, Wang L. Changes of potential evaporation in Northern China over the past 50 years [J]. Journal of Natural Resources, 2007, 22 (5): 683-691.]

[36] 刘昌明, 张丹. 中国地表潜在蒸散发敏感性的时空变化特征分 析 [J]. 地理学报, 2011, 66 (5): 579-588. [Liu C M, Zhang D. Temporal and spatial change analysis of the sensitivity of potential evapotranspiration to meteorological influencing factors in China[J]. Acta Geographica Sinica, 2011, 66 (5): 579-588.]

[37] 中国气象局. 气象数据网 [EB/OL]. (2016-08-30)[2017-01-03] http: //data.cma.cn/site/index.html. [China Meteorological Administration. Meteorological Data Network [EB/OL]. (2016-08-30) [2017-01-03]. http://data.cma.cn/site/index.html.]

[38] Wu S H, Yang Q Y, Zheng D. Delineation of eco- geographic region system of China[J]. Journal of Geographical Sciences, 2003, 13(3): 309-315

[39] 朱求安, 张万昌, 余钧辉. 基于 GIS 的空间插值方法研究 [J]. 江 西师范大学学报 (自然版), 2004, 28 (2): 183-188. [Zhu Q,

Zhang W C, Yu J H. Research on space interpolation methods based on GIS[J]. Journal of Jiangxi University (Natural Science), 2004,28(2): 183-188.]

[40] 曾红伟, 李丽娟, 张永萱, 等. 大样本降水空间插值研究-以 2009 年中国年降水为例 $[J]$. 地理科学进展, 2011, 30(7): 811818. [Zeng H W, Li L J, Zhang Y X, et al. Study on spatial interpolation of precipitation with large scale samples: A case study on 2009' s precipitation of China[J]. Progress in Geography, 2011,30(7): 811-818.]

[41] Fisher R A. Statistical Methods for Research Workers[M]. Edinburgh: Oliver and Boyd, 1946

[42] 魏凤英. 现代气候统计诊断与预测技术 [M]. 北京: 气象出版 社, 2007. [Wei F Y. Modern Climate Statistical Diagnosis and Prediction Technology [M]. Beijing: China Meteorological Press, 2007.]

[43] Gao G, Chen D L, Ren G Y, et al. Spatial and temporal variations and controlling factors of potential evapotranspiration in China: 1956-2000[J]. Journal of Geographical Sciences, 2006, 16(1):3-12.

[44] 尹云鹤, 吴绍洪, 郑度, 等. 近 30 年中国干湿状况变化的区域差 异[J]. 科学通报, 2005, 50(15): 1636-1642. [Yin Y H, Wu S H, Zheng D, et al. Regional differences of dry and wet condition of China during the last 30 years[J]. Chinese Science Bulletin, $2005,50(15): 1636-1642$. 


\title{
Spatio-temporal distribution characteristics of potential evapotranspiration and impact factors in China from 1961 to 2015
}

\author{
WU Xia, WANG Peijuan, HUO Zhiguo, BAI Yueming
}

(Chinese Academy of Meteorological Sciences, Beijing 100081, China)

\begin{abstract}
The spatio- temporal distribution characteristics of $E T_{\mathrm{o}}$ regarding national and four climatic regional scales were analyzed at annual, seasonal and decadal scales to obtain the spatiotemporal pattern for $E T_{0}$. Results show that the average annual $E T_{\mathrm{o}}$ is $620-1729 \mathrm{~mm}$ in China. The regions with the highest $E T_{\mathrm{o}}$ are mainly distributed in arid regions, while areas with lower $E T_{\mathrm{o}}$ are concentrates in semi-arid, humid and semi-humid regions at both 55-year average and different decadal scales. At a seasonal scale, the spatial distributions of $E T_{0}$ show a clear pattern: $E T_{0}$ is the highest in summer, followed by spring and autumn, and the lowest in winter, accounting for 39\%, $30 \%, 21 \%$ and $10 \%$ of average annual $E T_{\text {o }}$ respectively. Temporally, the average annual $E T_{0}$ decreased at a rate of $0.52 \mathrm{~mm} / \mathrm{a}$ from 1961 to 2015 , and the decreasing trend has a mutation phenomenon in 1972. Although there is an increasing trend since the last decade of the $20^{\text {th }}$ century, it did not detect the mutation year using Mann-Kendall methods. Trends of $E T_{\mathrm{o}}$ in different climate regions are distinctive. $E T_{0}$ in most sites decreased in arid region and humid regions, and the meteorological stations tended to decrease in arid regions more than in humid regions. In semi-arid and semi-humid regions, the number of sites is roughly equivalent regarding those that increased or decreased for $E T_{0}$. More than $85 \%$ of the sites in our country have $E T_{\mathrm{o}}$ mainly affected by wind speed and sunshine time. The decreasing trend of $E T_{\mathrm{o}}$ in recent 55 years was mainly caused by a decrease in wind speed, reduced sunshine time and a slight increase in vapor pressure. The major reason of $E T_{0}$ increase was vapor pressure, and the second were sunshine time and the lowest air temperature.
\end{abstract}

Key words : potential evapotranspiration; wet and dry climatic regions; spatio-temporal distribution characteristics; reason for change; China 